\title{
Genetic Variability Parameters for Yield and Yield Component Traits in the Mapping Population of Groundnut (Arachis hypogea)
}

\author{
Shweta Kademani* and Renuka Herakal \\ Department of Plant Physiology, University of Agricultural Sciences, \\ Dharwad - 580 005, Karnataka, India \\ *Corresponding author
}

\section{A B S T R A C T}

\section{Keywords}

Groundnut, GCV, PCV, Heritability, seed phosphorous content, Oil content.

\section{Article Info}

Accepted:

26 October 2017

Available Online:

10 December 2017
Groundnut is one of the major oilseed crops in the world. Variability studies are the basic studies to assess the genotypes for their variation in quantitative and qualitative characters. The extent of the genetic and non-genetic components of variation formulates proper breeding programme to reach the goal. A field experiment was conducted during kharif, 2010 at University of Agricultural Sciences, Dharwad to evaluate the genetic variation for yield and yield component traits in the mapping population. The field experiment was laid out in RCBD with 268 RILs (Recombinant inbreed lines) and their two parents (TAG $24 \mathrm{x}$ GPBD 4) (Gowda et al., 2002). The seed phosphorous content ranged from 0.33 to $0.82 \%$ with high heritability, high GCV, PCV and GAM. Oil content and shelling percentage had lower estimates of GCV and PCV indicating a limited genetic variability for these quality traits. The average value of the test weight was $45.69 \mathrm{~g}$ with moderate PCV and low GCV values (12.40\% and 8.38\%), respectively. The heritability and GAM estimates were moderate. The genetic advance was 5.33. The range for pod yield/plant was from 10.99 to 31.31 with a mean of 20.61. In the evaluated genotypes PCV and GCV values were moderate with high heritability with high GAM was observed.

\section{Introduction}

Groundnut is unique crop, combining the attributes of both oilseed and legume crops in the farming system of Indian agriculture. It is a valuable cash crop cultivated by millions of small farmers, because of its economic and nutritional value. It is an annual legume crop, grown mainly for quality edible oil (40-50\%) and easily digestible protein $(25 \%)$ in the seeds. Pod growth and development occupy an important position in determining the final quality and economic yield in groundnut crop. It is known as "king of oilseed crop" is believed to be native of Brazil (South America). It belongs to the family leguminoceae and sub-family papilionaceae. Globally, fifty percent of groundnut produce is used for oil extraction, 37 per cent for confectionery and 12 per cent for seed purpose. In India 80 per cent of the produce is used for direct food uses and one per cent is exported. Ground nut haulms provide excellent hay for feeding livestock.

In India, Karnataka stands third with an area of $0.86 \mathrm{~m}$ ha and a production of $0.60 \mathrm{~m}$ tons of pods and ranks fifth in productivity with $702 \mathrm{~kg} / \mathrm{ha}$ (Anon., 2005). The productivity of the crop in Karnataka is very low as 
compared to Gujarat (1335 kg/ha) and Tamil Nadu $(1597 \mathrm{~kg} / \mathrm{ha})$, due to lack of variability of good quality seed, low multiplication ratio during kharif and poor storage of the summer seeds produced poor nutrient management and the major areas being under rain fed condition (Anon., 2004). Variability studies are the basic studies to assess the genotypes for their variation in quantitative and qualitative characters. The extent of the genetic and non-genetic components of variation formulates proper breeding programme to reach the goal. More variability in characters indicates the scope for selection of genotypes for further genetic studies (Khote et al., 2009).

\section{Materials and Methods}

A field experiment was conducted during kharif, 2010 at College of Agriculture, University of Agricultural Sciences, Dharwad to evaluate the genetic variation for yield and yield component traits in the mapping population. The field experiment was laid out in RCBD with 268 RILs (Recombinant inbreed lines) and their two parents. Recombinant inbreed lines were developed from the cross TAG $24 \times$ GPBD 4. These comprise 268 RILs which segregated for agronomic trait, foliar disease reaction, nutritional and oil quality traits (Gowda et al., 2002).

A critical estimate and study on genetic variability is prerequisite for initiating appropriate breeding procedures in crop improvement programmes, which demands wide range of variability in a population. The determination of genetic variability and its partitioning in to various components in crop plants is necessary to have an insight in to genetic nature of yield and its components.

The most important objective in any crop improvement programme is to increase the seed yield. Extent of improvement of a character would depend mainly on the amount of variability in the population where selection has to be made. Further, the quantitative traits are governed by large number of genes and are more influenced by the environment.

Phosphorus content in plant sample was determined by following the vanadomolybdate yellow colour (Jackson, 1973). Hundred seeds were counted from the samples drawn from seed yield of each genotype and the weight of 100- seeds was recorded and expressed in grams.

The oil percentage was calculated using the following formula:

(Initial weight of powder-

Final weight of powder)

Oil percentage = ---------------------- X 100

Initial weight of powder

Pods harvested from the three selected plants of each genotype, were dried and weighed. The average pod weight of the three plants was expressed as pod yield per plant in grams.

\section{Results and Discussion}

Analysis of variances of experimental population is presented in the Table 1. This indicated that RILs included in the study differed significantly for all traits studied viz., seed phosphorous content, oil content, shelling percentage, test weight and pod yield. All the traits differed significantly at $1 \%$ level. The present findings are in agreement with the findings of Kadam et al., 2007, Khote et al., (2009), Ladole et al., (2009), and Shinde et al., (2010) for the traits of oil content, pod yield per plant and test weight.

Effectiveness of selection depends on the magnitude of genetic variability present for a 
particular character. It is necessary to study variability in respect of quantitative characters with reference to genetic parameters such as genotypic variance, phenotypic variance, heritability and genetic advance. An assessment of heritable and non-heritable components in the total variability observed is indispensable in adopting suitable breeding procedure. The heritable portion of the overall observed variation can be ascertained by studying the components of variation such as phenotypic coefficient of variation (PCV) and genotypic coefficient of variation (GCV).

The Genetic variability in the material was considered for further analysis. Range, mean, phenotypic and genotypic coefficient of variation, heritability estimates and predicted genetic advance as per cent of mean for characters studied are presented in Table 2. The seed phosphorous content ranged from 0.33 to $0.82 \%$ with high heritability $\left(\mathrm{h}^{2}\right)$, high GCV, PCV and GAM (Genetic Advance over mean). Thus, there is a wide variability for seed $\mathrm{P}$ content in the RILs. The research on genetic variability for this trait in groundnut is hardly available. John et al., (2006), Ladole et al., (2009) Khote et al., (2009) have found higher phenotypic coefficient of variation than genotypic coefficient of variation for most of the characters. However, the phenotypic coefficient of variation and genotypic coefficient of variation for seed $\mathrm{P}$ content remained same indicating least influence of environment on seed $P$ accumulation in groundnut seed

Table.1 ANOVA for the traits studied including yield and yield component traits in 268 RILs of TAG 24 X GPBD 4 cross in groundnut

\begin{tabular}{|c|c|c|c|c|c|c||}
\hline $\begin{array}{c}\text { Source of } \\
\text { variation }\end{array}$ & df & $\begin{array}{c}\text { Seed P } \\
\text { Content }(\boldsymbol{\%})\end{array}$ & $\begin{array}{c}\text { Oil content } \\
(\boldsymbol{\%})\end{array}$ & $\begin{array}{c}\text { Shelling } \\
\text { percentage }(\boldsymbol{\%})\end{array}$ & $\begin{array}{c}\text { Test } \\
\text { weight }(\mathbf{g})\end{array}$ & $\begin{array}{c}\text { Pod yield } \\
(\mathbf{g} / \mathbf{p l a n t})\end{array}$ \\
\hline \hline Replications & 1 & 0.04 & 3.19 & 32.36 & 37.08 & 13.87 \\
\hline Genotypes & 269 & $3.51 * *$ & $5.74 * *$ & $91.52 * *$ & $64.25 * *$ & $27.42 * *$ \\
\hline Error & 269 & 0.02 & 2.05 & 55.00 & 34.91 & 3.70 \\
\hline
\end{tabular}

* -significant at 5\% level probability

** - significant at $1 \%$ level probability

Table. 2 Genetic variability parameters for the traits studied including yield and yield component traits in 268 RILs of TAG 24 X GPBD 4 cross in groundnut

\begin{tabular}{|c|c|c|c|c|c||}
\hline Parameters & $\begin{array}{c}\text { Seed P } \\
\text { content }(\boldsymbol{\%})\end{array}$ & $\begin{array}{c}\text { Oil Content } \\
(\boldsymbol{\%})\end{array}$ & $\begin{array}{c}\text { Shelling } \\
\text { percentage }(\boldsymbol{\%})\end{array}$ & $\begin{array}{c}\text { Test weight } \\
(\mathbf{g})\end{array}$ & $\begin{array}{c}\text { Pod yield } \\
(\mathbf{g} / \mathbf{p l a n t})\end{array}$ \\
\hline \hline Mean & 0.62 & 47.21 & 72.26 & 45.69 & 20.61 \\
\hline Range & $0.33-0.82$ & $42.8-51.6$ & $26-82$ & $23.0-67.7$ & $10.9-31.3$ \\
\hline GCV (\%) & 21.16 & 2.88 & 5.91 & 8.38 & 16.71 \\
\hline PCV (\%) & 21.24 & 3.59 & 9.36 & 12.40 & 17.97 \\
\hline $\mathbf{h}^{\mathbf{2}}(\boldsymbol{\%})$ & 99.27 & 64.33 & 39.90 & 45.66 & 86.49 \\
\hline GAM (\%) & 43.43 & 4.75 & 7.69 & 11.66 & 32.01 \\
\hline GA & 0.27 & 2.24 & 5.56 & 5.33 & 6.59 \\
\hline
\end{tabular}

$\mathrm{GCV}=$ Genotypic coefficient of variation $\mathrm{PCV}=$ Phenotypic coefficient of variation $\mathrm{h}^{2}=$ Heritability $\mathrm{GAM}=$ Genetic advance as percent mean $\mathrm{GA}=$ Genetic advance 
Gupta et al., (2010) analyzing the seed phosphorous content in the groundnut reported that there was variation in seed phosphorous content among the groundnut genotypes. The availability of genetic variation is advantageous for crop improvement. Variability studies are the basic studies to assess the genotypes for their variation in quantitative and qualitative characters.

The knowledge on extent of genetic and nongenetic components of variation helps to formulate proper breeding programme to reach the goal. More variability in characters indicates the scope for selection of genotypes for further improvement. The genetic coefficient of variability gives an estimate of range of genetic variability for plant characters. A large variation in growth and yield is seen among the different improved cultivars of groundnut.

The oil content ranged from $42.87 \%$ to $51.67 \%$ and average value of the trait was $47.21 \%$. The PCV and GCV values were low. The heritability estimate was high with low GAM. The genetic advance was 2.24. Shelling percentage exhibited a wide variation, which ranged from 26 to $82 \%$ with overall mean of 72.26 .

The trait revealed low PCV and GCV values. The heritability recorded was moderate with low GAM. The characters viz., oil content and shelling percentage had lower estimates of GCV and PCV indicating a limited genetic variability for these quality traits thus less opportunity to further improve these traits. These results were in accordance with the Mukul kumar et al., (2010), Khote et al., (2009), Naazer et al., (2000).

The average value of the test weight was 45.69 $\mathrm{g}$ with moderate PCV and low GCV values $(12.40 \%$ and $8.38 \%)$, respectively. The heritability and GAM estimates were moderate. The genetic advance was 5.33. These findings are in accordance with the results obtained by Shinde et al., (2010), Naazer et al., (2000) and Prakash et al., (2000). The range for pod yield/plant was from 10.99 to 31.31 with a mean of 20.61. In the evaluated genotypes PCV and GCV values were moderate with high heritability with high GAM was observed for this trait indicating the presence of genetic variability to make effective selection for increasing pod yield (Mukul kumar et al., 2010; Khote et al., 2009; Prakash et al., 2000; Kadam et al., 2007 and John et al., 2005).

High value of heritability and high genetic advance has been noticed for seed $\mathrm{P}$ content and pod yield (John et al., 2005; Sarala and Gowda., 1998; Khote et al., 2009; Kadam et al., 2007) indicating that these traits are amenable for the selection. Moderate heritability coupled with low GAM were estimated for shelling percentage and oil content due to low genetic variability for these quality traits and selection for these traits may not be effective as reported by earlier writers (Reddy et al., 1987; Nadaf and Habib., 1990; Vaddoria and Patel., 1990; Mukul kumar et al., 2010; Meta, 2007; John et al., 2008).

\section{References}

Anonymous, 2004, National symposium on "Enhancing Productivity of groundnut for Sustaining Food and Nutritional Security, October-11-13, 2004 National Research Center for Groundnut, Junagadh, Gujarat.

Anonymous, 2005, Coverage and production of groundnut in India, International Crop Research Institute for Semi-Arid Tropics, Patancheru, Hyderabad.

Gowda, M.V.C., Motagi, B.N., Naidu,G.K., Diddimani, S.N. and Sheshagiri, R., 2002, GPBD 4: A Spanish bunch groundnut genotype resistance to rust and late leaf spot. Int. Arachis Newslett., 22:29-32.

Gupta, P.C., Koti, R.V., Chetti, M.B., Janagoudar, B.S., Hebsur, N.S., 2010, Effect of inositol on seed development and yield potential in groundnut. Karnataka J. Agric. Sci., 23(3): 506-508.

Jackson, M.L. 1973, Soil Chemical Analysis. Prentice Hall of India Private Limited New Delhi, pp. 38-82. 
John, K., Vasanthi, R. P., Venkateswarlu, O. and Sudhaka, P., 2005, Genetic variability and correlation studies among F1s and parents in groundnut (Arachis hypogaea L.). Legume Res. 28: 262-267.

John, K., Vasanthi, R. P., Venkateswarlu, O., 2006, Variability and heritability studies in groundnut (Arachis hypogaea L.). Legume Res. 29:225-227.

John, K., Vasanthi, R. P., Venkateswarlu, O., Muralikrishna, T. and Naidu, P. H., 2008, Genetic analysis and regression studies for yield and yield attributes in F2 segregating population of groundnut crosses. Legume Res., 31(1):225-227.

Kadam, P. S., Desai, D. T., Jagdish, U., Chauhan, D. A. and Shelke, B. L., 2007, Variability, heritability and genetic advance in groundnut. J. Maharashtra Agric. Univ., 32: 71-73.

Khote, A. C., Bendale, V. W., Bhave, S. G. and Patil, P. P., 2009, Genetic variability, heritability and genetic advance in some exotic genotypes of groundnut (Arachis hypogaea L.). Crop Res., 37(1, 2\&3):186191.

Ladole, M. Y., Wakode, M. M. and Deshmukh, S. N., 2009, Genetic variability and character association studies for yield and yield contributing traits in groundnut, Arachis hypogeae L. J. Oilseeds Res., 26 (special Issue):123-125.

Meta, H.R., 2007, Genetic variability, correlation and path coefficient analysis in bunch groundnut (Arachis hypogaea L.). M.Sc. (Agri) Thesis, Junagadh Agril. Univ., Junagadh.
Mukul Kumar, Noren Singh, Jamini Devi, L. and Ranjit Sharma., 2010, Genetic variability and correlation studies among advanced lines of groundnut under agro climatic conditions of North East Hill (NEH) Region. www.Indian Journals.com.

Naazer, Ali., Malik, S.N., Bashir Khurrm and Mirza, M. Y., 2000, Genetic variability, heritability and correlation studies in groudnut. Sarhad J. Agric. 16:533-36.

Nadaf, H. L., Habib, A. F., 1990, Correlation studies in groundnut (Arachis hypogeal L.). Agricultural Sciences Digest, 9:4-6.

Prakash, B. G., Khanure, S. K. and Sajjannavar, G. M., 2000, Variability studies in spreading groundnut. Karnataka J. Agric. Sci., 13:988-90.

Reddy, Y. M., Reddy, M. V., Reddy, K. T. and Reddy, D. R., 1987, Heritability and genetic advance in groundnut. J. Res., 15:102-107.

Sarala, B. S. and Gowda, M.V.C., 1998, Variability and correlation studies in segregating generation of inter sub specific crosses of groundnut (Arachis hypogaea L.). J. Res., 15:102-107.

Shinde P.P., Khanpara, M. D., Vachhani, J. H., Jivani, L. L. and Kachhadia, V. H., 2010, Genetic variability in Virginia bunch groundnut (Arachis hypogaea L.).Plant Archives, 10(2):703-706.

Vaddoria, M. A. and Patel, V. J., 1990, Genetic variability in Virginia runner ground (Arachis hypogaea L.), J. Oilseed Res., 7:130-132.

\section{How to cite this article:}

Shweta Kademani and Renuka Herakal. 2017. Genetic Variability Parameters for Yield and Yield Component Traits in the Mapping Population of Groundnut (Arachis hypogea). Int.J.Curr.Microbiol.App.Sci. 6(12): 3321-3325. doi: https://doi.org/10.20546/ijcmas.2017.612.386 